\title{
地図指摘法を用いたみどりの認知と評価 COGNITION AND EVALUATION OF "GREEN" USING THE MAP POINTING METHOD
}

\author{
網 藤 芳 男*，村川三郎**，西名大 作***，関 根 範 雄**** \\ Yoshio AMIFUJI, Saburo MURAKAWA, Daisaku NISHINA \\ and Norio SEKINE
}

\begin{abstract}
We proposed "the Map Pointing Method" that examines type, size and quality of green recognized by residence to evaluate it. A questionnaire survey was conducted for 329 college students chosen randomly who newly moved into Higash-hiroshima city in 1994, and the survey for the same set of respondents was repeated 3 times. We found that recognition of green by the respondents had become wider and more specific with enlargement of coverage of their activity at half a year after their environmental transitions. We considered that the green spaces usually recognized were located in 1,000 meter-radius area from each residence. The green was evaluated based on 4 aspects in this method, view, accessibility, management, environmental conservation. And a result showed that green at park was pointed higher, on the contrast, green at riverside was evaluated lowest in term of its accessibility.
\end{abstract}

Keywords: cognition of green space, evaluation of green, map pointing method, behavior route, environmental transition, college student 緑の認知, みどりの評価, 地図指摘法, 行動経路, 環境移行, 大学生

1. 序

人間は日常，様々な事物にとりまかれて生活している。その中で, 居住環境の質を高める要素として緑の存在の重要性が指摘されてい る。にもかかわらず, 緑地環境の保全・整備を進めていくにあたっ ては，木材価格の低迷などのために森林の管理放棄が進み, 都市化 とともに一部の農地は無秩序に宅地に転用され, 高い土地価格など のために公園整備がなかなか進まないなど多くの問題を抱えている。 一度失われた緑を回復させるには長い年月を必要とすることを考え ると, 特に都市的開発が急速に進んでいる地域では, 緑地をどのよ うに保全し，また新たに創出していくのかを明確にしていくことが， 良好な居住環境形成のための重要な視点と言える。そのためには, 緑地の現状に対する居住者の認知及び不満やニーズのような評価, 将来の住民構成などをふまえ, 緑地整備のあり方について様々な角 度から検討しておく必要がある。

筆者らは，地域環境評価の対象としてみどり ${ }^{* 11}$ を取り上げ，居

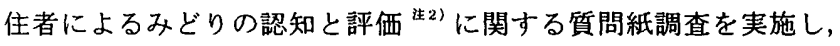
環境評価の事態での評価対象を含む環境の特性及び評価主体の個人 差の影響に着目した一連の研究を行っている ${ }^{1) ~}$ 大学入学により居住場所を移動するという環境移行を経験している 大学生を対象者としている。そして, 同一の対象者に繰り返し回答 を求めることで, みどりの認知と評価の経時的な変容過程について
検討する。また, 環境移行前の出身地の環境特性と評価対象者の価 值観を取り上げ, みどりの評価に対するこれらの影響についても検 討を加える。

みどりの認知と評価を把握する方法として，「地図指摘法」を提 案する。環境評価では, 評価しようとする目的に合わせて評価対象 や評価項目，尺度構成などが設定される。本研究では，居住者が日 常認知していると考えられるみどりの種類や空間的な大きさ, 評価 などについて検討することを目的としている。そのためには，緑が 認知されている場所を特定し，その場所の評価を得る必要がある。 「地図指摘法」の手続きは, 居住者が緑が存在していると思う領域 を地図上に記入させ，その後に，記入された領域にあるみどりの評 価を求めるものである。これは人間の空間認識と評価とを同時に得 ることを意図している。また, 対象者の居住場所及び日常の行動経 路の記入も求め,それらと認知された場所との関係を分析すること により，日常的に認知されている空間範囲の検討も行う。

\section{2. 既往研究との関連}

人による空間の認知を把握する方法としては, 白紙に特定の空間 内容の絵地図を描かせる方法と，あらかじめ用意された地図に様々 な情報を記入させる方法の二つが代表的である。

前者は, 認知地図, イメージマップなどと呼ばれる「心の中の地
* 農林水産省農業研究センター 主任研究官

** 広島大学工学部 教授. 工博

*** 広島大学工学部 助教授. 博士 (工学)

**** 四国電力株式会社建設部 修士(工学)
Senior Researcher, National Agriculture Research Center, MAFF

Prof., Faculty of Engineering, Hiroshima Univ., Dr. Eng.

Assoc. Prof., Faculty of Engineering, Hiroshima Univ., Dr. Eng.

Dept. of Construction, Shikoku Electric Power Co., Inc., M. Eng. 
図」を描画によって白紙に再生させる方法である。ケヴィン・リン チによるスケッチマップ法がその代表であり"，その後認知地図を 測定するための様々な方法が開発され用いられている。例えば，安 藤ら よる再生と口述による再生を併用し, 緑地空間の合成イメージを把 㨋している。また, 加藤”) は, 描き順と描かれた空間要素に着目し てイメージマップを分析し，集落空間の特性を把握している。

後者では，対象地域の地図を媒介として，地図上に調㚗者が意図 する要素・領域・経路などを記入させる。この方法は，前者に比べ ると比㲦的新しい方法と言える。例えば，增田ら ${ }^{(0)}$ ，井上ら "1 は， 地図上に日常生活での「行動ルート」「意識するみどり」などを記 入させ, 緑の認識強度と行動ルートとの相互関倸などを捉えている。 また, 加藤 ${ }^{12)}$ は, 居住者に共通した空間イメージを把暒する方法 として「空間意識図」を案出し，「自然が多い」「景色がいい」 「見た目が悪い」などと思う場所を指摘させ，それらの基準での価 值判邀に基づいて空間を選別させている。同様に，アンディら ${ }^{(3)}$ ， イグナシオら ${ }^{141}$ は，「景触の変化した」「保護すべき」「開発す べき」などと思う場所を，地形図，もしくは航空写真を用いて記入 させ，これを「地図認知法」と呼んでいる。

本研究では，人によって認知されている空間を数量的に表現する ことと，分析にあたって主観的な解貌を入れないようにすることを 意図して，地図を用いて緑のある場所を指摘させる方法を摇用した。 その際, 加藤 ${ }^{121}$ やアンディら ${ }^{13)}$, イグナシオら ${ }^{14)}$ が行った価值判 断に基づく場所の指摘ではなく，「日常よく目にする緑」のように 場所の指摘が価值判断を伴わない形式をとり，その直後に指摘され た場所に対する評価を求めるという手順を用いている。これは，場 所の認知と場所に対する評価とを区別し，しかも両者を一度に把握 することを意図している。

また，緑が日常的に認知される空間の筑囲について，高橋ら ${ }^{18)}$ は，居住場所の周辺空間の緑被率と居住者の緑に対する充足意識の 程度との関係から，日常生活の緑意識を支配する圈域をほぼ $250 \mathrm{~m}$ 图 と推定している。また，井手ら ${ }^{19)}$ は，自宅から500m以内の「みどり 空間」が想起されやすい要素を持っていることを指摘している。

本研究では，緑が認知されている場所を「地図指摘法」によって 捉え，合わせて增田ら ${ }^{(0)}$ ，井上ら ${ }^{11}$ と同様に，地図上に日常の行

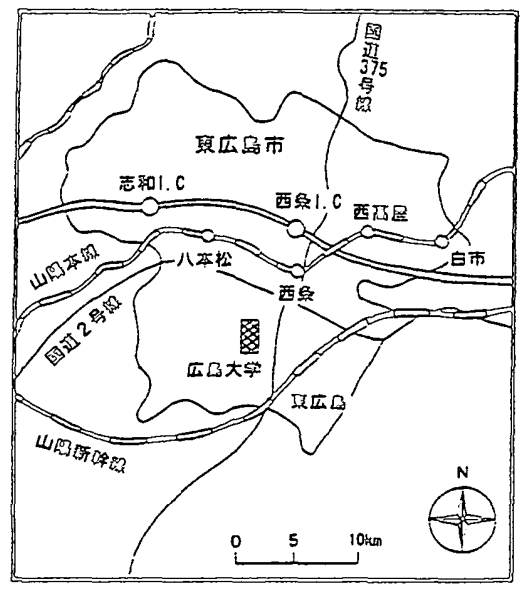

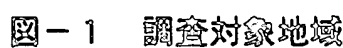
動経路や居住場所の記 入を求め, 緑空間と居 住場所との関係をみる ことで，日常的に認知 されている空間筑囲に ついて考察する。

\section{3. 硕究の方济}

3. 1 相甾の䍀要 本研究では，広島県

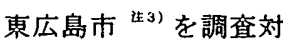
象地域とし，同市に居 住する大学生を対象者 として，1994年の 4 月， 7 月, 10 月の 3 時期に
「生活環境とみどりに関する意識調㚗」を実施した。調㚗対象地域 の概要を図ー1に示す。

調査対象者の選定にあたり，調査対象地区として広島大学を中心 に学生用の住宅が比較的まとまっている6 地区を設定した（図ー2 参照）。第 1 回（4月）の調查では，各地区で約 100名，1994年度 の新入生と上級生（2 年生以上）との比率がほぼ等しくなるように 全体で 606票の調査票を配布した。第 2 回（7月）と第 3 回（10月 の調查では, 1994年 4 月から東広島市に居住を始めた学生のみに調 㚗票を配布した。配布・回収は 3 回の調㚗とも調㚗員による戸別訪 問により行った。訪問配布・訪問回収のため, 調㚗票の回収時に一 部の回答者本人から直接に質問を受けた以外は，原則として事前の 教示はしていない。

3 回の調查とも有効回収率は $95 \%$ 以上であった。同一の調㚗対象 者の回答が 3 回の調㚗とも有効とみなしたものは 329 票であり，こ れを以下の分析に供した。

\section{2 調㸖票の設計}

「生活環境とみどりに関する意識調查」は，通常の質問紙調㚗票 と地図記入の調亘票からなり, 前者は, 1) 地域のイメージ（S D 法 7 段階尺度 30 項目），2）生活環境評価（5段階尺度30項目），3）緑 の棬成要素の認識（5段階尺度18項目），4）みどり全体（身近にあ ると思うみどり全体）の評価（7段階尺度 8 項目），5)生活価值篗 （4段階尺度12項目），6)生活満足度（5段階尺度 9 項目），及び 対象者の属性などの調疽項目で楼成した。地図記入の調查票へは, これらへの回答の後に記入することを調㚗対象者に求めた。 地図記入の調查票はA 3 サイズ 3 枚で構成した。1 枚目は, 記入 方法の説明と, 以下に述べる指摘された緑の領域を評価するための 回答知及び記入例からなる。2枚目は東広島市の広島大学と西条町 を中心とした主要地域を含む白地図（以下，A票と呼ぶ：1/25, 000 地形図：東西7. $75 \mathrm{~km}$, 南北 $11.0 \mathrm{~km}$, 後述の図 -2 の筑囲に相当）で

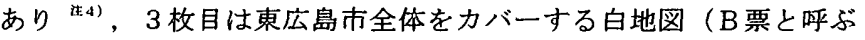
: 1/50,000地形図) である。

地図記入にあたっては，対象者に(1)居住場所，(2)日常的に利用し ている道路（以下では，行動経路と呼ぶ），(3)緑があると思う場所 （みどりの指摘場所，あるいは単に指摘場所と呼ぶ），(4)指摘場所 の評価の順に記入することを求めた。

日常の行動経路の記入では，1) 通学路，2)週に 3 回以上通る道路， 3）週に 1 回以上通る道路を区別して記入することを求めた。以下で は，通学路と 3 回以上通る道路とを分析対象とした。

みどりの指摘場所については，1）身近にあると思うみどりの評価 で具体的に思い浮かべた場所，及び，2）日常よく目につく緑のある 場所の筑囲を梅円のような䦥じた頒域の形で指摘することを求めた。 指摘された場所の評価では，日常よく目につく緑のある場所に対 してのみ，その場所の評価を求めた。評価項目は「見た目の感じが よい」「レクリエーションなどで利用しやすい」「管理が適切にな されている」「地域の環境を良好な状態に保っている」の 4 項目で 桷成し，それぞれ「そう思う(5点)」から「そうは思わない(1点)」 までの 5 段階で評定を求めた。

また，評価の個人差をみるために，対象者の出身地の環境特性を 表す項目として農業活力度に基づく市町村䕱型 ${ }^{\circledR 5}$ ，及び生活価值 䂓の項目から対象者の特性を表す項目として「自然と親しむ生活」 
と「都市的な生活」のどちら がよいと思うかという個人の

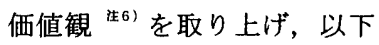
の分析に用いた。法》

\section{3 データの加エ方法}

本調查では, A 票, B 票の

2 種類の白地図を用意したが，より広域である B 票への記入は数例 しかなく, 日常の行動圈やみどりとして認知される空間の範囲は $\mathrm{A}$ 票の地図内に収まると考えられる。したがって，以下の分析ではA 票のみを分析の対象とした。

A 票に記入された(1)居住場所，(2)行動経路，(3)みどりの指摘場所 は，プログラムを作成し対象者ごとにデジタイザーを用いて入力し た ${ }^{(18)}$ 。

行動経路のデータについては，道路の分岐している地点（以下で はこれを結節点と呼ぶ）を基準として，全対象者から402個の結節 点が得られた。結節点によりすべての行動経路は598個の経路に分 節された。さらに, デジタイザー入力により, 結節点と経路及び居

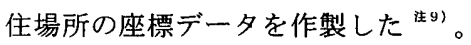

指摘場所については, 最初にポリゴン形式で入力し, 次いで50m $\times 50 \mathrm{~m}$ を単位として, $155 \times 220$ 個のグリッドのメッシュのデータに

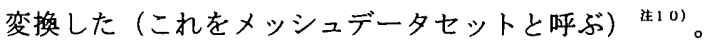

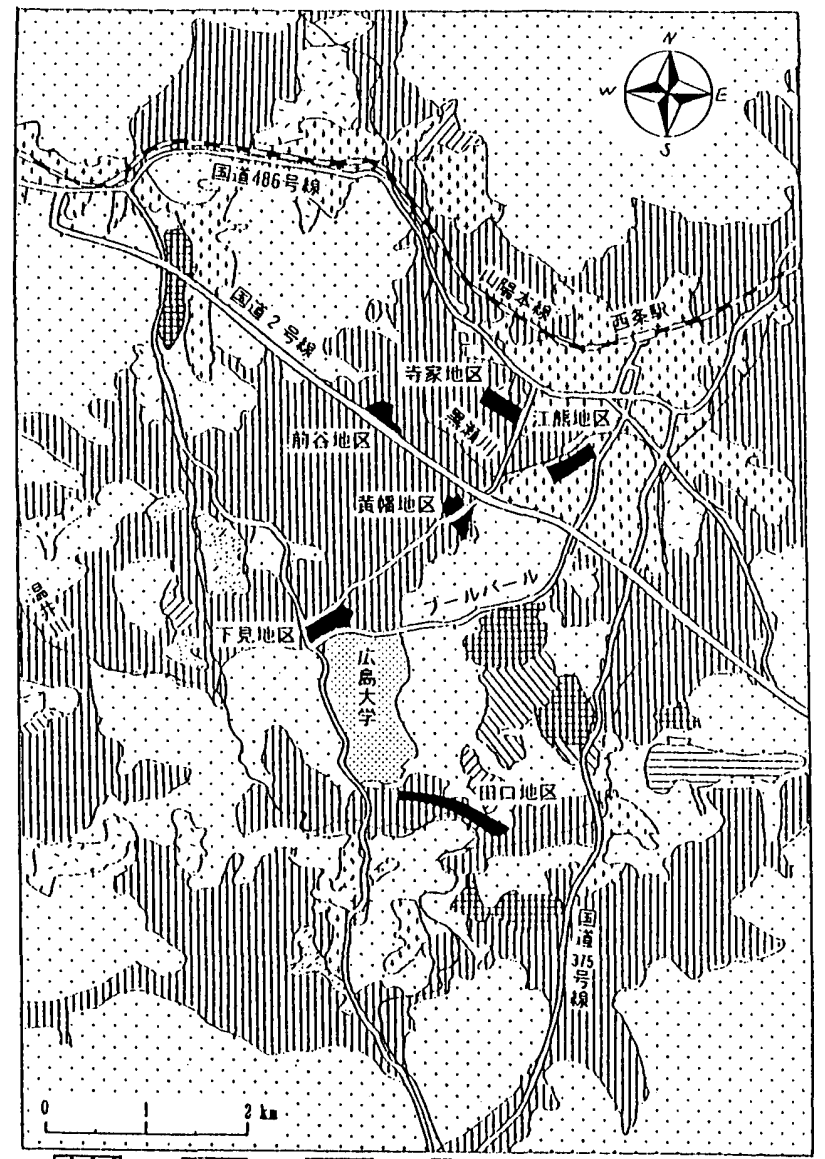

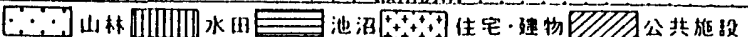

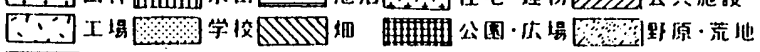
調查対象地区（6地区）

\section{図一 2 対象地区の土地利用}

\section{4 分析方法}

対象者の行動経路のデータを用いて，各経路の選択頻度を求めた。 さらに, 地形図上の結節点の座標データを用いて各経路の距離を算 出し, それを加算して各対象者の行動経路の総延長距離を求めた。

みどりの指摘場所の全体的傾向をみるために，ポリゴン形式，メ ッシュ形式のデータともに, オーバーレイ表示を行った。またメッ シュ形式のデータから，メッシュごとの頻度及び指摘率を算出した (111)。さらに, これを土地利用データと組み合わせて, 土地利用区 分ごとに集計し，土地利用別のメッシ之指摘数及び指摘率を算出し た。また, 指摘場所 1 ケ所あたりの平均面積は, 累積指摘メッシュ 数を指摘場所数で除し，それを実面積に換算した。

指摘場所と行動経路・居住場所との関係をみるために，指摘場所 ごとに，行動経路と指摘場所との最短距離を求めた。ここでの最短 距離は, 対象者のすべての行動経路の結節点と指摘場所のポリゴン 表示の結節点とのすべてを組み合わせた 2 点間の距離の最小值を指 標とした。また, 居住場所から指摘場所までの距離は, 居住場所と 指摘場所の重心との距離を指標とした。

指摘場所の評価を行うにあたり，土地利用区分別の評価得点を以 下の手順で算出した。まず，指摘場所の評価得点をその場所の領域 に含まれる各メッシュの評価得点とした。次に, 土地利用区分に該 当するメッシュの評価得点を加算し, それを該当する区分の総メッ シュ数で除したものをその土地利用区分の評価得点とした。

\section{4 対象地域の土地利用}

図ー 2 に対象地域の土地利用を示す。この図は, 対象地域の土地 利用を 12 種類に区分し（図一 2 の凡例参照, ただし凡例では道路と

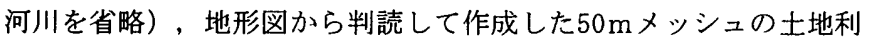
用図を基に，細部を省略したものである。

表ー 1 に，土地利用区分別のメッシュ数と割合とを示す。土地利 用の割合をみると，「山林」が $44 \%$ と最も高く，次いで「水田」 28 \%,「住宅・建物」 $12 \%$ の順に高い。またこの地域の特徵として, ため池が多く点在しており，「池沼」が $2.5 \%$ を占めている。

\section{5 行動経路の分析}

\section{1 行動経路の選択頻度}

図-3に，対象者の行動経路の選択頻度を，6つの対象地区のう ち寺家地区を例として示寸。選択率が $60 \%$ 以上となっている経路で は，通学路として記入された場合がほとんどである。4月，7月， 10月と経時的に経路の数が増加している。また, 個々の経路の選択 頻度も増加する傾向がみられる。他の 5 地区でも同様の傾向を示し ている。このことから, 対象者全体でみると, 行動範囲が漸次扡大 していることがわかる。

\section{2 行動経路の総延長距離}

図一 4 に, 行動経路の総延長距離を, $2,000 \mathrm{~m} ゙$ との距離帯別に, 


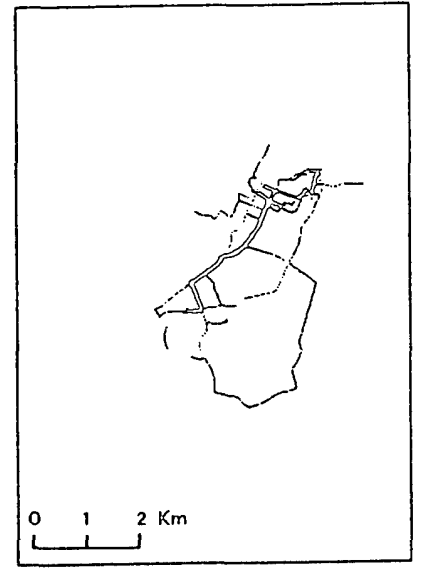

a) 4 月

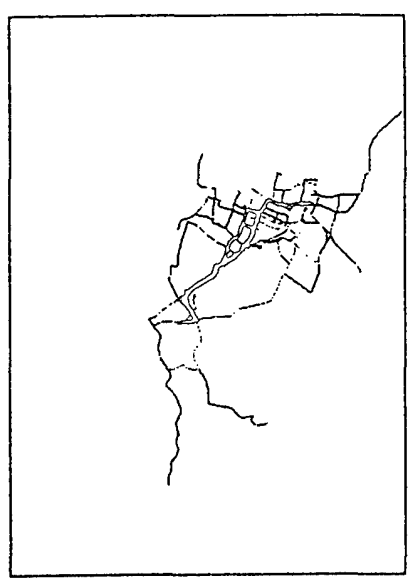

b) 7 月

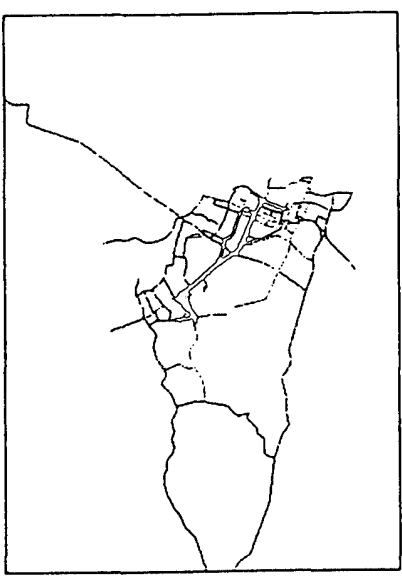

c) 10月

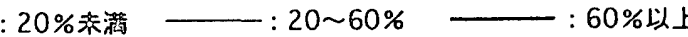

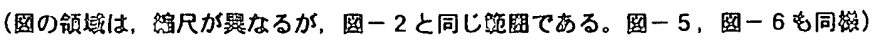

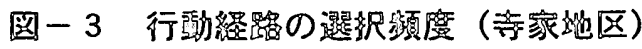

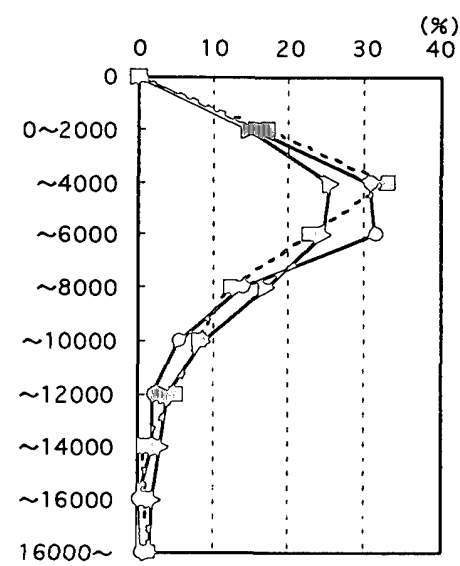

(m)

$\sim 4$ 月- - - - 7月—七10月

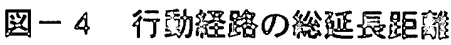

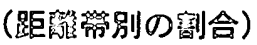

行動経路を記入した対象者全体に対寸る割合で示す。行動経路の長 さは, 各時期とも $2,000 \mathrm{~m} か ら 6,000 \mathrm{~m}$ の筑囲に半数以上が集中してい る。経時的にみると， 7 月では $8,000 \mathrm{~m}$ から $12,000 \mathrm{~m}$ の人が若干增加 し，10月ではさらに 4, 7 月で大きなピークのみられる距離帶の割 合が小さくなり，それ以上の距離帯の割合が增加する傾向がみられ

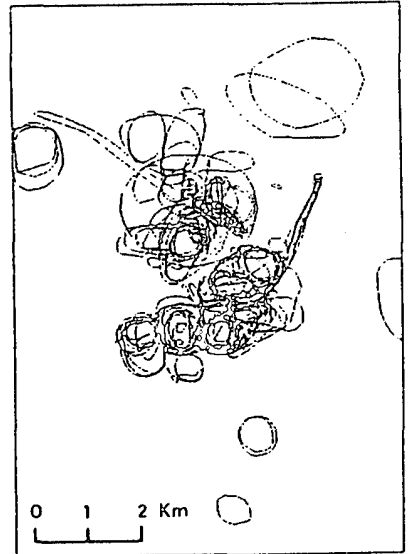

a) 4 月

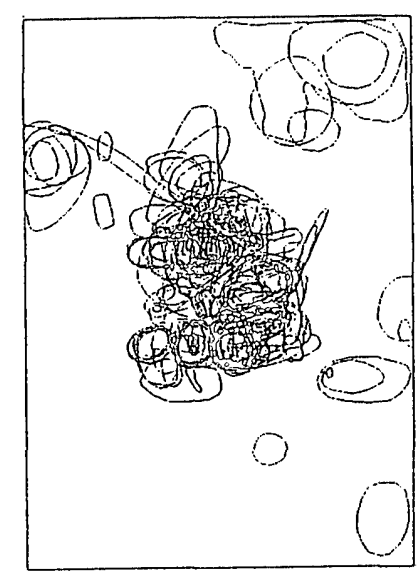

b) 7 月

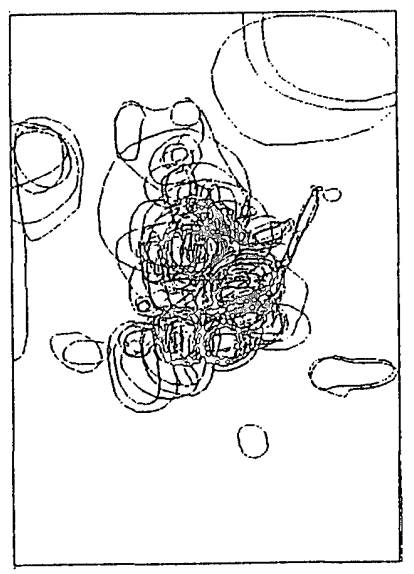

c) 10月

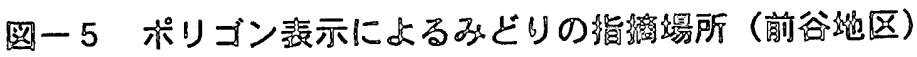

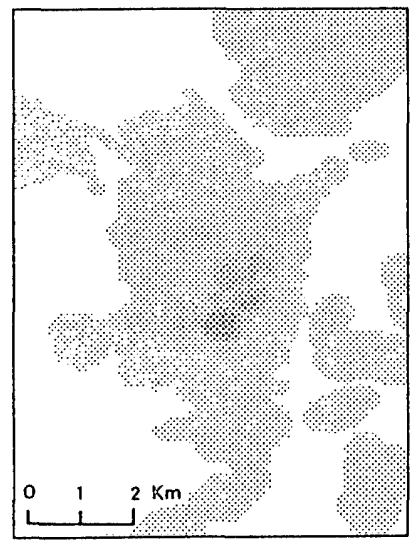

a) 4 月

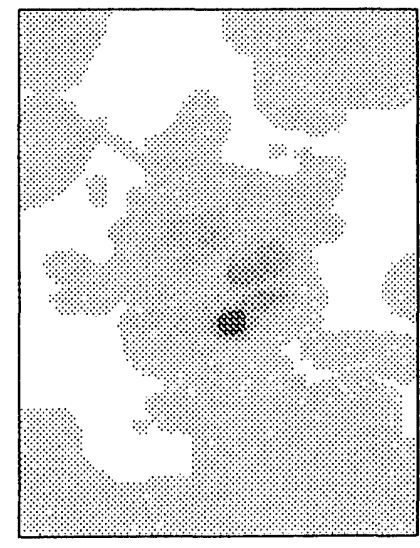

b) 7 月

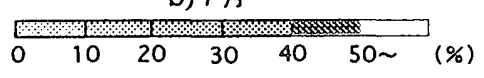

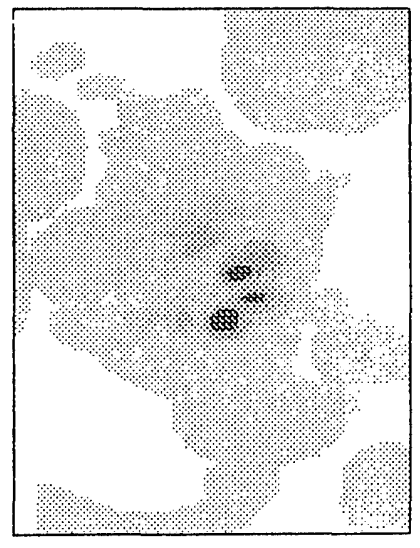

c) 10 月

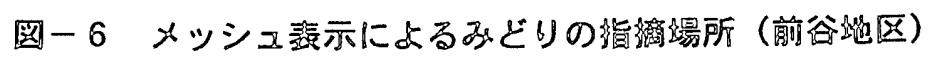

\section{6 みどりの恉摘場所の分析}

\section{1 対皱者ごとの指摘場所の数}

各対象者の指摘場所, そのような指 摘場所でさらに評価がなされていた場 所（以下，評価された場所と呼ぶ）の 頻度と平均指摘数を，それぞれ表 -2 ， 表 -3 に示す。 3 回の調查とも $80 \%$ 以 上の対象者がみどりの指摘場所を記入 していた。一人平均の指摘数でみると， 指摘場所，評価された場所ともに経時 的に増加している。指摘場所数の分布 をみると，この期間中に指摘数が 3 か ら4の䉇囲に収束する傾向がみられる。 評価された場所の場合も，指摘場所ほ ど䫓著ではないが, 同様の傾向がみら れる。これらは，個々人で時期に差は あるが，居住開始から半年後までの間 にみどりとして認知される対象が拡大 し, ある時期から選択的にいくつかの 特定の場所が強く認知されるようにな るという認知変容のプロセスを支持し ていると考える。

\section{2 みどりの指䐱埸所の分布}

図一 5 に，対象者が指摘した場所を ポリゴン表示で重ね合わせたものを， 前谷地区を例として示す。ただし同図 は比較のために 3 時期ともにA表に指 摘場所を記入していた対象者のみを表 示している。これより, 時間経過とと 
もに指摘場所が増える傾向が読み取れる。また，指摘場所について は，対象者に共通して認識されている場所があることが認められる。

さらに, 全対象者が指摘した場所について各メッシュごとの指摘 率を算出した。これを図一6に示す。この図から，鏡山公園のある 位置がみどりのある場所として最もよく認識されていることがわか る。また, 図一 5 のポリゴン形式の表示と合わせてみると, 各調査 地区と広島大学との間の空間, 及び西条駅 (中心市街地) と広島大 学とを結ぶ道路（ブールバール）に沿った空間に指摘場所が集中し ていることがわかる。

\section{3 土地利用区分別にみた指摘場所の特徴}

表一 4 に, メッシュ単位による土地利用区分別の指摘場所数とメ ッシュ指摘率とを示す。メッシュ指摘数でみると，各時期とも「山 林」が最も多く, 次いで「水田」「公園・広場」「学校」が多く指 摘されている。メッシュ指摘率では, 「公園・広場」「学校」の指 摘率が高い。二れは前者では鏡山公園の, 後者では広島大学の区分 内にしめる面積比が大きく，そこに指摘場所が集中しているためで ある。「山林」「水田」ではメッシュ指摘数が大きいにも関わらず 指摘率は低い。山林や水田は地域全体に分布しているにも関わらず, 一部の特定の場所が指摘されていることがわかる。

土地利用区分ごとにメッシュ指摘率をみると，「学校」の 4 月か ら 7 月の変化を除いてどの区分でも指摘率は経時的に増加している。

\begin{tabular}{crrrrrr}
\multicolumn{1}{c}{ 表一 2} & \multicolumn{3}{c}{ 指摘場所数 } \\
\hline & \multicolumn{9}{c}{ 4月 } & \multicolumn{2}{c}{ 7月 } & \multicolumn{2}{c}{10 月 } \\
場所指摘数 & 頻度 & \multicolumn{1}{c}{$\%$} & 頻度 & $\%$ & 頻度 & \multicolumn{1}{c}{$\%$} \\
\hline 1 & 58 & 20.7 & 31 & 10.6 & 27 & 8.9 \\
2 & 74 & 26.4 & 62 & 21.2 & 50 & 16.4 \\
3 & 72 & 25.7 & 73 & 25.0 & 84 & 27.6 \\
4 & 40 & 14.3 & 62 & 21.2 & 76 & 25.0 \\
5 & 19 & 6.8 & 39 & 13.4 & 32 & 10.5 \\
6 & 9 & 3.2 & 12 & 4.1 & 19 & 6.3 \\
7 & 4 & 1.4 & 8 & 2.7 & 13 & 4.3 \\
8 & 2 & 0.7 & 4 & 1.4 & 3 & 1.0 \\
9 & 1 & 0.4 & 1 & 0.3 & & \\
14 & 1 & 0.4 & & & & \\
合計 & 280 & 100.0 & 292 & 100.0 & 304 & 100.0 \\
\hline 一人平均指摘数 & 2.4 & \multicolumn{6}{c}{3.3} \\
\hline
\end{tabular}

\begin{tabular}{|c|c|c|c|c|c|c|}
\hline \multirow{2}{*}{ 場所指摘数 } & \multicolumn{2}{|c|}{ 4月 } & \multicolumn{2}{|c|}{ 7月 } & \multicolumn{2}{|c|}{ 10月 } \\
\hline & 頻度 & $\%$ & 頻度 & $\%$ & 頻度 & $\%$ \\
\hline 1 & 73 & 26.1 & 57 & 19.5 & 57 & 18.8 \\
\hline 2 & 74 & 26.4 & 81 & 27.7 & 76 & 25.0 \\
\hline 3 & 71 & 25.4 & 65 & 22.3 & 87 & 28.6 \\
\hline 4 & 22 & 7.9 & 37 & 12.7 & 48 & 15.8 \\
\hline 5 & 7 & 2.5 & 19 & 6.5 & 14 & 4.6 \\
\hline 6 & 2 & 0.7 & 2 & 0.7 & 3 & 1.0 \\
\hline 7 & 3 & 1.1 & 1 & 0.3 & 3 & 1.0 \\
\hline 9 & 1 & 0.4 & 1 & 0.3 & & \\
\hline 13 & 1 & 0.4 & & & & \\
\hline 合計 & 254 & 100.0 & 263 & 100.0 & 288 & 100.0 \\
\hline 一人平均指摘数 & 1.9 & & 2.1 & & 2.3 & \\
\hline
\end{tabular}

さらに, 指摘場所 1 ヶ所あたりの面積でみると, その平均值は経時 的に $1.3 ， 1.8 ， 2.1\left(\mathrm{~km}^{2}\right)$ と増加している。これらから, 半年の間 に, 認知されるみどりの領域は, 面積的に拡大していることが指摘 できる。

6. 4 行動経路及び居住場所とみどりの指摘場所との関連

図-7に, 行動経路の行動距離帯別（図-4参照）に対象者ごと のみどりの指摘場所の数を, 4 月を例として示す。この図から, 行 動距離が長い人ほどみどりの指摘場所が多いことがわかる。7 月, 10月でも，4月ほど顕著ではないが，同様の傾向がみられる。環境 移行直後は行動範囲の広い人ほど空間認知は急速に進むが, 時期が 経つにつれて空間認知の範囲は行動範囲の広狭に影響されなくなる ということが言えよう。

図一8に, 行動経路と指摘場所との関係について, 行動経路から 指摘場所までの距離帯別に指摘場所数を示す。3 時期ともに指摘場 所は最短距離が $250 \mathrm{~m}$ から $750 \mathrm{~m}$ 範囲で最も多い。また，4月から 10 月にかけて経時的にこの距離帯の指摘場所が増加している。

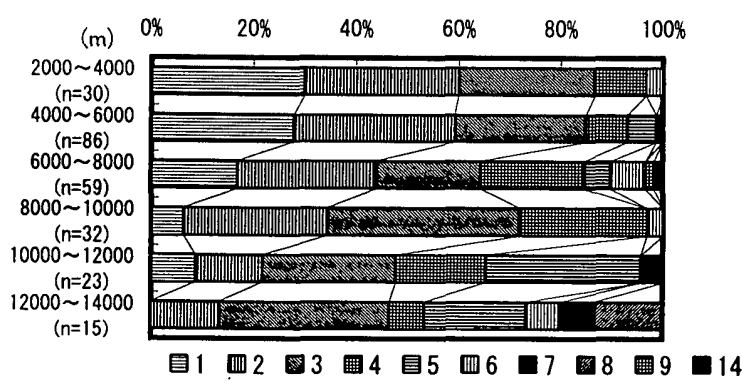

図一7 行動距離带別みどりの堨所指摘数 (4月)

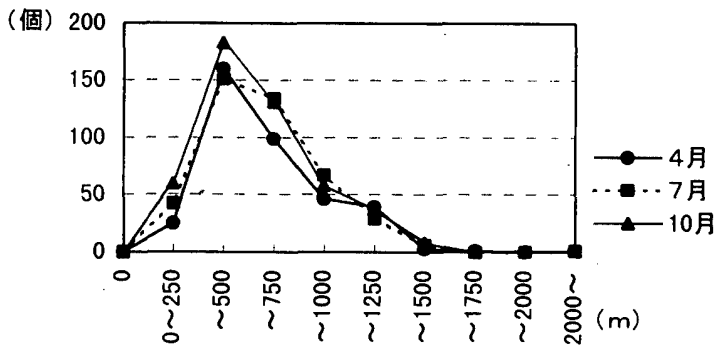

图-8 行動释路と指摘場所との最短距離帯別の 䀜所指摘数

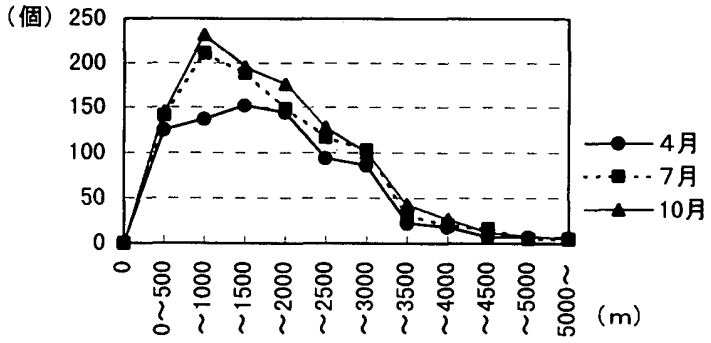

图-9 居住場所と指摘場所との距離帯別の 㔠所指摘数

表一4 土地利用別のメッシュ指摘数と指摘率

\begin{tabular}{|c|c|c|c|c|c|c|c|c|c|c|c|c|c|c|}
\hline & & 山林 & 水田 & 住宅 & 工場 & 池沼 & 野原 & 㚼 & 河川 & 学校 & 公圆 & 道路 & 公共施設 & 累皘指摘メッシュ \\
\hline \multirow[t]{2}{*}{4 月 } & 指摘メッシュ数 & 53082 & 22029 & 5108 & 158 & 2730 & 244 & 3464 & 1216 & 10863 & 9347 & 2157 & 426 & 148077 \\
\hline & メッシュ指摘率 & 3.5 & 2.3 & 1.3 & 0.2 & 3.2 & 0.3 & 4. 7 & 1.9 & 19.4 & 19.1 & 6.3 & 1. 9 & 4. 3 \\
\hline 7月 & $\begin{array}{l}\text { 指㹍メッシュ数 } \\
\text { メッシュ指摘本 }\end{array}$ & $\begin{array}{r}70751 \\
4.7\end{array}$ & $\begin{array}{r}35493 \\
3.7\end{array}$ & $\begin{array}{r}7375 \\
1.8\end{array}$ & $\begin{array}{l}251 \\
0.3\end{array}$ & $\begin{array}{r}3769 \\
4.4\end{array}$ & $\begin{array}{l}671 \\
0.9\end{array}$ & $\begin{array}{r}6206 \\
8.5\end{array}$ & $\begin{array}{r}1930 \\
3.0\end{array}$ & $\begin{array}{l}9397 \\
16.8\end{array}$ & $\begin{array}{r}11812 \\
24.2\end{array}$ & $\begin{array}{r}2563 \\
7.5\end{array}$ & $\begin{array}{l}583 \\
2.6\end{array}$ & $\begin{array}{r}216088 \\
6.3\end{array}$ \\
\hline 10月 & $\begin{array}{l}\text { 指摘メッシュ数 } \\
\text { メッシュ指摘本 }\end{array}$ & $\begin{array}{r}81792 \\
5.5\end{array}$ & $\begin{array}{r}44837 \\
4.7\end{array}$ & $\begin{array}{r}10014 \\
2.5\end{array}$ & $\begin{array}{l}382 \\
0.4\end{array}$ & $\begin{array}{r}6250 \\
7.3\end{array}$ & $\begin{array}{l}928 \\
1.2\end{array}$ & $\begin{array}{l}7410 \\
10.1\end{array}$ & $\begin{array}{r}2517 \\
3.9\end{array}$ & $\begin{array}{r}13444 \\
24.0\end{array}$ & $\begin{array}{r}13962 \\
28.6\end{array}$ & $\begin{array}{l}3394 \\
10.0\end{array}$ & $\begin{array}{l}814 \\
3.6\end{array}$ & $\begin{array}{r}254005 \\
7.4\end{array}$ \\
\hline
\end{tabular}


(严均罚偭角点)
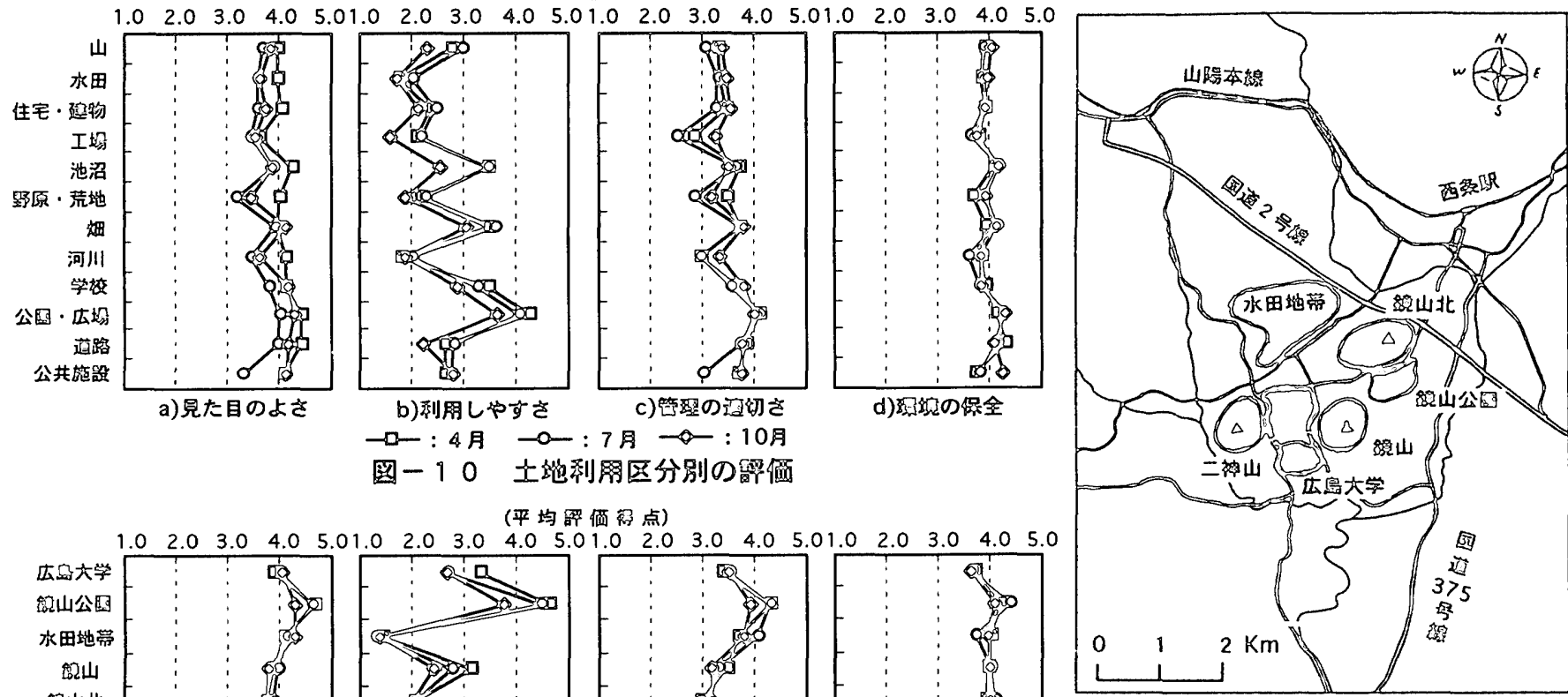

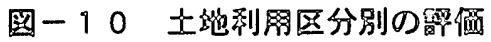

(平均罚価霞点)

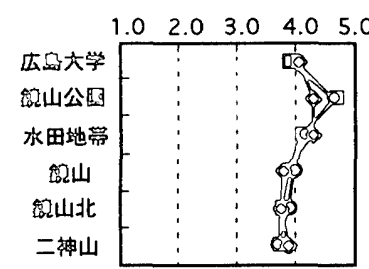

a)見た目のよさ

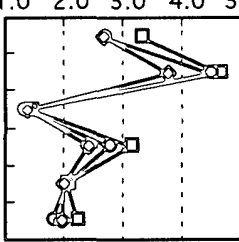

b)利周しやすを

口: 4月 -

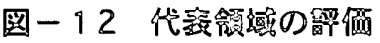

図一 9 に，居住場所から指摘場所までの距離を横軸にとり，距離 帯別の指摘場所数を時期別に示す。この場合の指摘場所は $500 \mathrm{~m} か ら$ $2,000 \mathrm{~m}$ 筑围で最も多い。時期別にみると，指摘場所数は増加して おり，特に 4 月から 7 月にかけての増加が顕著である。以上の結果 は, 高橋ら ${ }^{(5)}$ の $250 \mathrm{~m}$ 圈, 井手ら ${ }^{(6)}$ の500m圈よりもさらに広い筂囲 のみどりが日常的に認知されていることを示唆している。特に居住 場所との関係でみた場合，少なく見積もっても認知されているみど りの空間筑囲は居住場所から $1,000 \mathrm{~m}$ 圈であると言えよう。

\section{7 恉䐱場所のみどりの評偭の分析}

\section{1 土地利用区分別のみどりの評洒}

図一10に土地利用区分別の平均評価得点を時期別に示す。 $4 つ$ つ 評価項目の中では，「利用しやすさ」の面で各区分の評価の差が最 も大きく現れ，「見た目のよさ」「環境の保全」での差は小さい。

「見た目のよさ」ではどの土地利用区分の評価も高い。区分別で は「公園・広場」「道路」の評価がやや高く，「工場」「野原・荒 地」の評価がやや低い。「利用しやすさ」では区分によって肯定的 な評価と否定的な評価に分かれている。「公園・広場」の評価が最 も高く, 次いで「学校」「烟」「池沼」が肯定的に評価されている。 逆に,「河川」の評価が最も低く,「水田」「野原。荒地」「工場」 「住宅・建物」の評価も低い。また，時間の経過にともない，各区 分の評価が低くなる傾向がみられる。「管理の適切さ」では全体的 にみるとやや肯定的な評価が得られている。「公園・広場」次いで 「道路」「畑」「公共施設」の評価が高く,「工場」「河川」で低 い。評価の低い区分では，「河川」のように経時的に評価が高まる 傾向がみられるものもある。「環境の保全」では「見た目のよさ」 と同様にどの土地利用区分の評価も高い。「公園・広場」「池沼」 「道路」の評価がやや高く，「工場」「野原・荒地」でやや低い。 「公園・広場」はどの評価項目でも評価が高く, 居住者, 特に大学

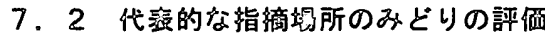

生にとって「公園・広場」が緑地として

重要視されていることがわかる。

指摘場所の評価にあたっては, 最初に, ポリゴン形式の累積表示 （図 5) 及びメッシュ形式の場所の指摘率（図 6) に基づいて，指 摘の多い6つの領域（以下，代表領域と呼ぶ）を抽出した。図-11 に代表領域の位置を示す。

表一 5 に，代表領域の指摘数と指摘率を示す。 6 つの代表領域の 中では，「鏡山北」の指摘数が最も多い。3つの山林のうち「鏡山 北」が田口地区を除く 5 地区から最も近くにあり, 居住場所の周囲 でも標高の高い山であるためと考えられる。代表領域指摘率の変化 をみると，経時的に増加する傾向がみられる。指摘数でみた場合，

「水田地帯」の指摘数俚他の領域と比べて多くないが, 経時的な指 摘数の増加は最も顕著である。「水田地帯」の場合, 緑の質や量が 季節的に変化することにより，認知されやすくなると考えられる。

図一12に，各代表領域の評価を時期別に示す。「見た目のよさ」 では「鏡山公園」の評価が 3 時期とも高い。「利用しやすさ」では 「鏡山公園」で高く,「沓田地帯」で特に低い。また，全領域で経 時的に評価が低くなる傾向がみられる。この傾向は「鏡山」で最も 顕著である。利用という側面では, 実際の利用に伴い次第に現実的 な評価がなされるようになると考えられる。「管理の適切さ」では 山林の評価が低い。これは, 村川ららでもふれたように, 山林管理 が行われなくなってきていることが反映されていると考えられる。

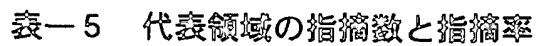

\begin{tabular}{|c|c|c|c|c|c|c|c|}
\hline & & 広的大学 & 的山公国 & 水田 & 18山 & 䟚山北 & 二神山 \\
\hline \multirow[t]{2}{*}{ 4月 } & 指描敦 & 59 & 51 & 21 & 55 & 67 & 24 \\
\hline & 指桼筷 $(\%)$ & 17.9 & 15.5 & 6.4 & 16.7 & 20.4 & 7.3 \\
\hline \multirow[t]{2}{*}{ 7月 } & 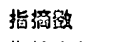 & 51 & 43 & 33 & 65 & 59 & 20 \\
\hline & 指满睝(\%) & 15.5 & 13.1 & 10.0 & 19.8 & 17.9 & 6.1 \\
\hline \multirow[t]{2}{*}{ 10月 } & 指攡㬿 & 64 & 55 & 36 & 66 & 78 & 26 \\
\hline & 指猫卧 (\%) & 19.5 & 16.7 & 10.9 & 20.1 & 23.7 & 7.9 \\
\hline
\end{tabular}


8 対象者の特性によるみどりの評価

8. 1 出身地別のみどりの評価

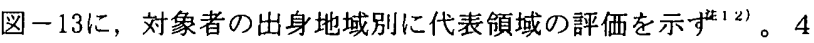
つの評価項目を比較すると，「見た目のよさ」と「環境の保全」の 評価で出身地別の差が大きい。「見た目のよさ」については，都市 的地域の出身者の評価が高いが，時間の経過とともに差が小さくな る傾向がみられる。「環境の保全」では，「鏡山」に対する農村的 地域出身者の評価が低く，都市的地域・中間地域の評価が高い。経 時的にみるとこの差は小さくなっている。逆に「広島大学」に対す る評価は，4月では差がなく，経時的に都市的地域出身者の評価が 高くなっている。「管理の適切さ」については，評価に差があるよ うにみえるが，一貫した傾向はみいだせない。「利用しやすさ」に ついては，出身地別の評価の差は 4 つの評価項目の中で最も小さい。 「見た目のよさ」「管理の適切さ」のような評価は, 視覚的認知と 結びついて, 居住場所の移動の直後には出身地の環境の相違が強く 反映され，経時的に居住場所の認知が進むにつれて徐々に出身地の 環境意識が弱まると考えられる。「利用のしやすさ」の評価は，行 動と結びついて，実際の場所の利用経験や利用可能性の判断に基づ いて行われ，過去の経験の影響を受けにくいと思われる。

\section{2 価値観別のみどりの評価}

図ー14に，対象者の価值観別に代表領域の評価を示す圷12!。出身 地別の評価と比べると，価値観別の評価の差は小さい。また，評価 の経時的変化については, 顕著な傾向はみいだせない。本研究で行 ったような場所が特定された事態での評価では，対象に対する価值 判断に際して個人の価值観の影響が小さいことが分かる。さらに，

「自然」「やや自然」「やや都市」の3カテゴリーでみた場合,

「やや自然」の対象者の評価値が，「見た目のよさ」「睘境の保全」 では低く，「利用しやすさ」「管理の適切さ」では高くなる傾向が みられる。このことから，自然志向と都市志向とは対極にあるので はなく，「やや自然」を志向している人は，都市的な生活も望むけ れども居住環境の自然が豊かであることを重視するという立場にあ ると思われる。

(平均科価得点)

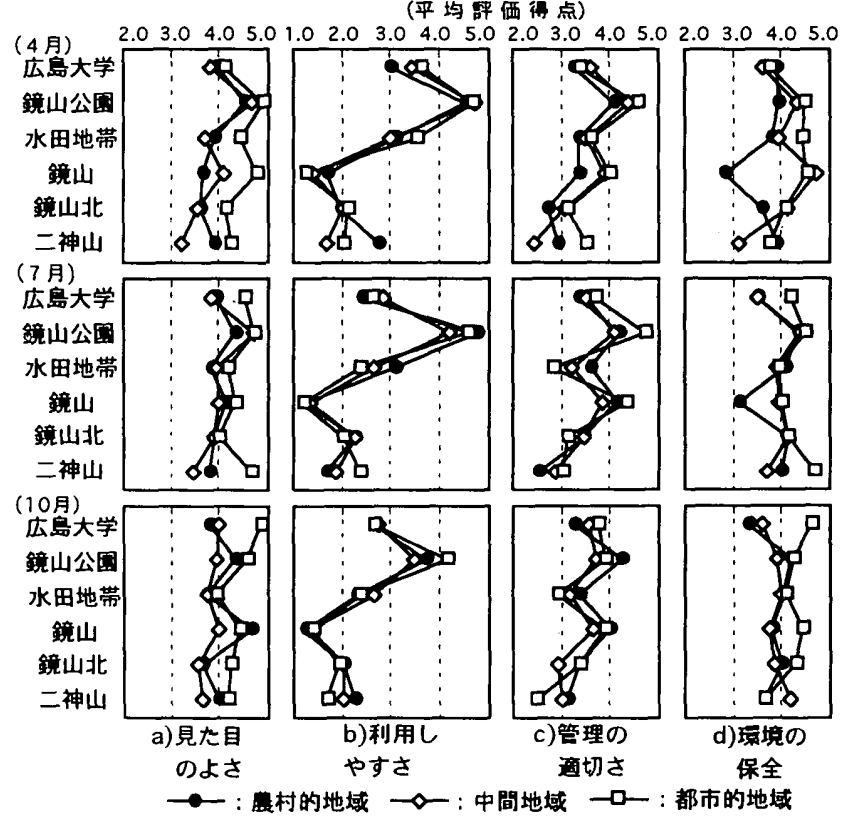

図一-13 指摘場所の出身地別評価
9. 結語

本研究では, 場所の移動を伴う環境移行を経験している大学生を 対象者とすることで, 環境移行の事態におけるみどりの認知と評価 の経時的な変容について検討した。その際，居住者が身近に意識し ているみどりを評価する方法として「地図指摘法」を提案し，この 手法を用いて居住者が日常認知していると考えられるみどりの種類 や空間的な大きさ，評価について検討した。得られた知見をまとめ て以下に示す。

1) 行動経路の分析結果から, 場所の移動を伴う環境移行を経験し ている大学生の行動範囲は, 移行後半年の間に徐々に拡大している ことがわかった。

2 ) みどりの指摘場所の数や分布の分析結果から, 環境移行後半年 の間に，目につくみどりとして指摘される領域が拡大し，ある時期 から選択的にいくつかの特定の場所が強く認知されるようになると いう認知変容のプロセスのあることを示唆した。緑として認知され る領域の拡大については, 異なる対象として認識される領域が漸次 增加することと，個々の領域も面積的に拡大する傾向にあるという 2 つの側面で確認した。

3) 行動経路及び居住場所とみどりの指摘場所との関連分析の結果 から，行動籁囲の広さと緑の認知のされやすさには相関関係がある ことを指摘した。また, 認知されている緑の空間範囲は居住場所か ら少なくとも $1,000 \mathrm{~m}$ 圈であると推定した。従来の知見よりも広い範 囲の緑地が日常的にみどりとして認識されていることを指摘した。 4) 指摘された場所の評価では，4種類の評価項目のうち利用のし や寸さの評価で差異が顕著に認められ，特に利用面での「河川」の 評価が極端に低いことが示された。「池沼」が肯定的に評価されて いたことと対置すると，東広島市では公共空間としての河川の整備 にあたっては, 適切な管理によって緑の質を高めレクリエーション などの利用面に配慮する必要のあることが指摘される。

5 ) 対象者の出身地別及び価值観別の評価結果から，見た目や環境 保全という視覚的に捉えられやすい側面の評価では過去の経験が評 価に影響すること，特定の指摘場所の評価に対する個人の価値観の

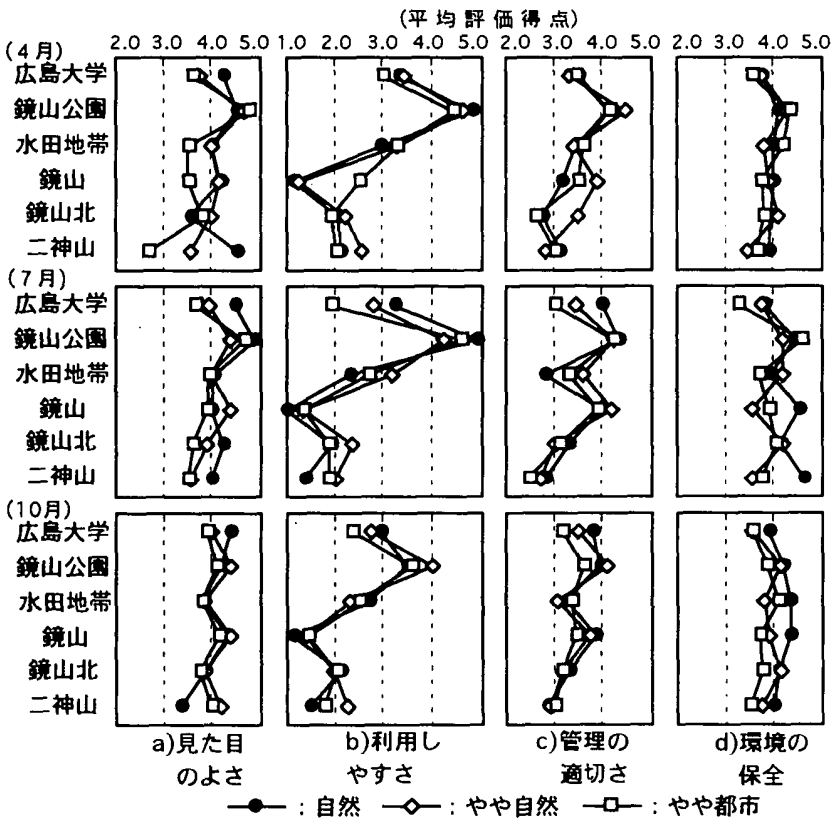

图-14 指摘場所の価値観別評価 
影響は小さいことが示唆された。

なお，この調㚗では, 場所の認知と場所に対する評価とを区別し

て捉え，しかも両者を一度の質問紙調查で把握することを意図して，

「地図指摘法」を用いたみどりの評価手法を提案した。このように 価値判断を伴わない形で場所を指摘させることにより，認知された 場所に対する多面的な評価が可能となると考える。本研究では，対 象者を居住期間が半年までの大学生という特定の階層に限定してい る。今後は，一般の住民に適用する際の手続きを简略化し，評価法 の有効性を確認するとともに，一般住民のみどりの認知・評価につ いて検討していく必要があると考える。

毁辞

調查に参加していただいた広島大学の学生の方々，及び分析に協力してい ただいた広島大学平成 7 年度卒踚生櫻井理恵氏に感锹します。本研究を進め るにあたり、科学技術庁総合研究「システムと人間の調和のための人間特性

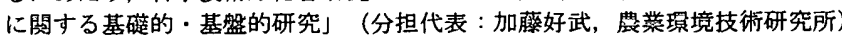
の研究费の一部を使用した。記して爵意を表する。

注

本諭文は，既発表文献 ${ }^{4}$.5) をもとに加等・再䋹したものである。

1) 本研究では「緑地」となみどり」という用語を区別して用いている。ま た、単に「緑」と言う場合は，二れを「緑地」と同艇に用いている。前 者の「緑地」は植物で被豭された現実世界に存在している空間のことで あり，後者の「みどり」は「緑地」が人によって楒知されたものを意味 している。両者は，心理学でいう「物理的瓄境」と「心理的環境」の区 別に相当する。

2)「みどりの認知と評価」は，正確に言うと「緑の認知と認知されたみど りの評価」であるが，煩雑になるので認知と評価とをセットで考える場 合にはこのように表現する。

3）広島県東広島市は，広島県のほほ中央部に位咠し，広島市の東に隣接し ている。市域面楦は $288 \mathrm{~km}^{2}$ で, 平成 7 年度国势調㚗によると, 総人口 11 万 3935 人，世带数 4 万 4220 世帯である。広岛大学の移㛙と広島中央 クノポリス地域の指定，及び広島市のベッドタウン化により，人口が急 增し，都市化が進行しつつある。大学移転にともない学生向け住宅の建 設が急增し，费地の宅地転用によるスプロール化現象が特に市域の中心 部で起きている。

4） A票に示した篮囲は，国土地理院発行の $1 / 25,000$ 地形図の 4 図幅（安芸 西条，白市，清水原，田万里市）にまたがっている。

5）対奥者の出身市町村のテーータに，農林漁鄴金融公庫 ${ }^{17)}$ が行った全国市

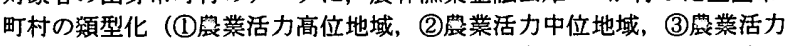
低位地域，(4)都市地域）を適用し，対象者の出身地の幊境特性を表す力 テゴリー指標とした。この指標は(1) (4)の順に都市化の進行の程度と対 応していると考えた。(1)農業活力行為地域の出身者は他の類型と比べて 極端に少ないため，出身地別の分析から除いている。ここでは，(2)を落 粟地域，(3)を中間地域と呼ぶことにする。なお，調查地域の東広島市は この市町村穎型では中間地域に分類されている。

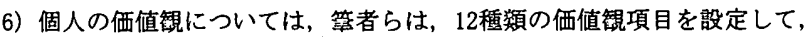
调查研究を進めている 18)。例えば,「A：自然と親しむ生活がよい, と「B：都市的な生活がよい」のように対になる 2 つ意見を提示し， 「Aに近い」「やAに近い」「やBに近い」「Bに近いの 4 段階 の尺度で評定することを回答者に求めた。今回の調查では，「Bに近い (都市的な生活がよい)」と回答した人が少なく，価值䍉別の分析では このカテゴリーを除外し，「自然」「やや自然」「や都市」の 3 つの カテゴリーを用いている。

7）意践調查の斦問項目群1) 8)については，個人の価値稳分析に用いた 1 項目以外は本碖文の中で触れないので, 項目内容の詳細は省咯する。

8）デジタイザーでの入力及びデータの加工はN8BBASICで作成したプログラ ムにより処理した。なお，平均值などを求める統計処理にはSASを使用
した。

9）婵続する結節点間の経路が長い場合や曲がっている場合は補助の結節点

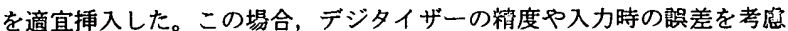
寸ると，経路の入力や指摘場所のポリゴン形式の入力の間隔を、例えば 等間隔のように, 綮密に設定する必要はないと考えた。

10）この場合， $50 \mathrm{~m} \times 50 \mathrm{~m}$ グリッドの中心点が指搝場所の領域に含まれるかど うかを判定させるプログラムを作成して，中心点が含まれる埸合にその グリッドをメッシュ形式の指描場所とみなし、メッシュ単位でのXY座 標形式のデータセットを作成した。

11）土地利用区分別の指摘率を計算する場合の分母は，便宜的に作成した士 地利用図の筑囲に含まれている各土地利用区分のメッシュ数とした。

12）「水田」と「二神山」の出身地別, 価値観別の評価值は，全体の指摘数 が20から 36の筑囲とサンブル数が少ないため，参考值の扱いとした。

\section{参得立旅}

1) 網落芳男・井手 任・横張 真：住民に上る都市近郊樹林地の機能評価 一住民の属性による評価傾向の差異について一，農村計画学会誌，Vol. $11(3)$, pp. 21-29, 1992

2）網藤芳男・田中隆：みどり評価の広域比皎一広域首都圈を対象とした 意践調查による一，環境情報科学、Vol. 20 (2)，pp. 104-108、1991

3）網藤芳男・村川三郎・西名大作・関根笵雄：大学生の環境移行に伴うみ どりの慧躘・評価の变容に関する研究 その 1 . 調查概要と調查時期別 分析, 日本建築学会大会学術暲演梗概集D-1, pp. 867-868, 1995.8

4）網落芳男・村川三郎・西名大作・関根筑雄：大学生の彊境移行に伴うみ とりの認識・評価の変容に関する研究 その 4 . 地形図を用いた場所に 指摘によるみどり懪境の評価, 日本建築学会中国・九州支部研究報告, Vol. 10, pp. 173-176, 1996. 3

5）網藤芳男・村川三郎・西名大作・関根筑雄：大学生の環境移行に伴うみ どりの認識・評価の変容に関する研究 その 4 . 行動経路とみどりの認

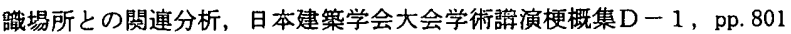
$-802,1996.9$

6）村川三郎・網壂芳男・西名大作・関根筑雄：評価者の個人特性を考䜿し た生活㻴境評価モデルに関する研究その1. 有識者による境評価結 果, 日本建筑学会大会学術謤演梗概集 D - 1, pp. 749-750, 1996.9

7) ケヴィン・リンチ：都市のイメージ，岩波書店, $\mathrm{pp} 276,1968$

8）安藤 昭・五十嵐日出夫・赤谷隆一：都市周辺部における緑地環境のイ メージ解析，造園傕誌, Vol. 52(5), pp. 330-335, 1989

9) 加藤仁美：「イメージマップ」による個人の㻴境イメージと焦落空間特 性一都市・農村のマージナルエリアにおける都市化の權造と綮境計画 第 3 報一，日本建築学会計画系踚文集，No. 493，pp. 185-193，1997.3

10）增田 昇・阿部大就・中類 捱・下村泰彦：日常生活行動における緑の イメージ模造に閧寸る研究，造固雜誌，Vol. 50(5)，pp. 315-320，1987

11）井上和彦・增田 昇・阿部大就・中瀨 熙・下村泰彦：緑との接触行動 を基調とした緑の認躘特性に関する研究，造園雑誌，Vol. 51 (5), pp. 234 $-238,1988$

12）加藤仁美：「空間意践図」による住民の共通な環境イメージー都市・鹿 村のマージナルエリアにおける都市化の荤造と環境計画 第2 報一, 日 本建筑学会計画系論文集, No. 479, pp. 159-168, 1996

13）アンディ・グワナン・吉田博宣：ボゴール市アーバンフリンジの景䚁と

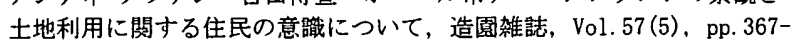
372,1994

14）イグナシオ・アリスティムニョ・吉田博宣：神戸市アーバン・フリンジ の景钼変化に関する住民の選好に関する研究，ランドスケープ研究， Vol. 58(5), pp. 249-252, 1995

15）高㛢理宫男・野田穹樹：都市環境における快適性の指棉としてのみどり

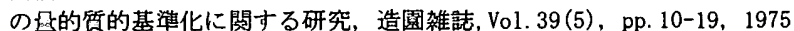

16）井手 任・根本泰人・井手久登：「みどり空間」の親しみやすさに関す る基磪的考察, 日本都市計画学会学術研究論文集, No. 20, pp. 349-354, 1985

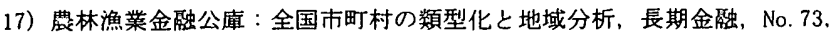
pp 165,1992

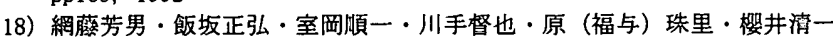

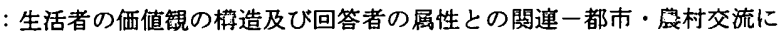
閣寸る地域比故（その 2) 一, 農村生活研究, Vol. 40(2), pp. 10-17, 1996. 6 